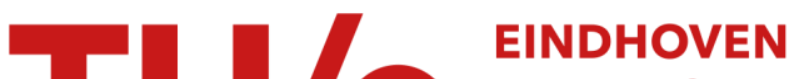 \\ UNIVERSITY OF \\ TECHNOLOGY
}

\section{Silicon surface passivation by atomic layer deposited Al2O3}

\author{
Citation for published version (APA): \\ Hoex, B., Schmidt, J., Pohl, P., Sanden, van de, M. C. M., \& Kessels, W. M. M. (2008). Silicon surface \\ passivation by atomic layer deposited Al2O3. Journal of Applied Physics, 104(4), 044903-1/12. [044903]. \\ https://doi.org/10.1063/1.2963707
}

DOI:

10.1063/1.2963707

Document status and date:

Published: 01/01/2008

\section{Document Version:}

Publisher's PDF, also known as Version of Record (includes final page, issue and volume numbers)

\section{Please check the document version of this publication:}

- A submitted manuscript is the version of the article upon submission and before peer-review. There can be important differences between the submitted version and the official published version of record. People interested in the research are advised to contact the author for the final version of the publication, or visit the $\mathrm{DOI}$ to the publisher's website.

- The final author version and the galley proof are versions of the publication after peer review.

- The final published version features the final layout of the paper including the volume, issue and page numbers.

Link to publication

\section{General rights}

Copyright and moral rights for the publications made accessible in the public portal are retained by the authors and/or other copyright owners and it is a condition of accessing publications that users recognise and abide by the legal requirements associated with these rights.

- Users may download and print one copy of any publication from the public portal for the purpose of private study or research.

- You may not further distribute the material or use it for any profit-making activity or commercial gain

- You may freely distribute the URL identifying the publication in the public portal.

If the publication is distributed under the terms of Article 25fa of the Dutch Copyright Act, indicated by the "Taverne" license above, please follow below link for the End User Agreement:

www.tue.nl/taverne

Take down policy

If you believe that this document breaches copyright please contact us at:

openaccess@tue.nl

providing details and we will investigate your claim. 


\title{
Silicon surface passivation by atomic layer deposited $\mathrm{Al}_{\mathbf{2}} \mathrm{O}_{\mathbf{3}}$
}

\author{
B. Hoex ${ }^{1, a)}$ J. Schmidt, ${ }^{2}$ P. Pohl, ${ }^{2}$ M. C. M. van de Sanden, ${ }^{1}$ and W. M. M. Kessels ${ }^{1, b)}$ \\ ${ }^{1}$ Department of Applied Physics, Eindhoven University of Technology, P.O. Box 513, 5600 MB Eindhoven, \\ The Netherlands \\ ${ }^{2}$ Institut für Solarenergieforschung Hameln/Emmerthal (ISFH), Am Ohrberg 1, D-31860 Emmerthal, \\ Germany
}

(Received 15 May 2008; accepted 4 June 2008; published online 26 August 2008)

\begin{abstract}
Thin $\mathrm{Al}_{2} \mathrm{O}_{3}$ films with a thickness of $7-30 \mathrm{~nm}$ synthesized by plasma-assisted atomic layer deposition (ALD) were used for surface passivation of crystalline silicon $(c-\mathrm{Si})$ of different doping concentrations. The level of surface passivation in this study was determined by techniques based on photoconductance, photoluminescence, and infrared emission. Effective surface recombination velocities of 2 and $6 \mathrm{~cm} / \mathrm{s}$ were obtained on $1.9 \Omega \mathrm{cm} n$-type and $2.0 \Omega \mathrm{cm} p$-type $c$-Si, respectively. An effective surface recombination velocity below $1 \mathrm{~cm} / \mathrm{s}$ was unambiguously obtained for nearly intrinsic $c$-Si passivated by $\mathrm{Al}_{2} \mathrm{O}_{3}$. A high density of negative fixed charges was detected in the $\mathrm{Al}_{2} \mathrm{O}_{3}$ films and its impact on the level of surface passivation was demonstrated experimentally. The negative fixed charge density results in a flat injection level dependence of the effective lifetime on $p$-type $c$-Si and explains the excellent passivation of highly B-doped $c$-Si by $\mathrm{Al}_{2} \mathrm{O}_{3}$. Furthermore, a brief comparison is presented between the surface passivations achieved for thermal and plasma-assisted $\mathrm{ALD} \mathrm{Al}_{2} \mathrm{O}_{3}$ films prepared in the same ALD reactor. (C) 2008 American Institute of Physics. [DOI: 10.1063/1.2963707]
\end{abstract}

\section{INTRODUCTION}

Surface passivation of crystalline silicon $(c-\mathrm{Si})$ is becoming increasingly important in photovoltaics. Evidently, an excellent level of surface passivation is a requisite for high-efficiency $c$-Si solar cells. However, also for more conventional solar cells, which experience an increasing surfaceto-volume ratio due to the cost-driven reduction of the cell thickness, surface passivation is becoming of vital importance. Recombination losses at the $c$-Si surface can be reduced by two fundamentally different strategies. Because the recombination rate is proportional with the interface defect density, the first strategy is based on the reduction of the number of defects states at the semiconductor surface. The surface defect density can, for example, be lowered by chemical passivation of unsaturated $\mathrm{Si}$ bonds (i.e., dangling bonds) by atomic hydrogen. The second strategy is based on the fact that surface recombination processes involve both electrons and holes. By the application of an internal electric field below the $c$-Si surface, either the electron or hole concentration can dramatically be reduced at the position of the $c$-Si surface. Consequently, surface recombination is significantly reduced and the surface recombination velocity roughly scales with the minority carrier concentration that is present at the $c$-Si surface. Both surface passivation strategies can be adopted by the application of thin films on the $c$-Si surface.

Currently three thin film materials are industrially employed for surface passivation of $c$-Si solar cells. The state of the art in surface passivation is obtained by thin films of thermally grown silicon dioxide (thermal $\mathrm{SiO}_{2}$ ) and effective

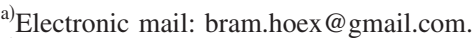

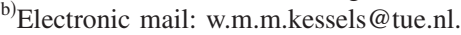

surface recombination velocities of 2 and $12 \mathrm{~cm} / \mathrm{s}$ have been reported on $1.5 \Omega \mathrm{cm} n$-type and $1 \Omega \mathrm{cm} p$-type $c$-Si, respectively. ${ }^{1}$ The excellent level of surface passivation can mainly be attributed to the very high interface quality of thermal $\mathrm{SiO}_{2}$ on $c$-Si. This high interface quality is warranted by the fact that the $\mathrm{SiO}_{2}$ is thermally grown into the $c-\mathrm{Si}$ wafer at elevated temperatures (in the range of $900-1100{ }^{\circ} \mathrm{C}$ ). Hence, the final interface quality remains rather unaffected by the initial $c$-Si surface condition. The interface quality is generally further improved by extensive postdeposition processing involving an annealing in a $\mathrm{H}_{2}$ containing atmosphere (e.g., a forming gas annealing). The best interface quality is, however, obtained when first a sacrificial $\mathrm{Al}$ film is deposited on the $\mathrm{SiO}_{2}$ film followed by an annealing at $450{ }^{\circ} \mathrm{C}$ (the so-called "alnealing"). ${ }^{2}$ Moreover also a small positive fixed charge density $\left(10^{10}-10^{11} \mathrm{~cm}^{-2}\right)$ is present in the thermal $\mathrm{SiO}_{2}$ layer that provides field-effect passivation by shielding holes from the $c$-Si surface. ${ }^{3}$ Due to the high processing temperatures required to thermally grow a $\mathrm{SiO}_{2}$ film, only $c$-Si with a low impurity content such as float zone (FZ) Si can be used without significant bulk lifetime degradation. ${ }^{4}$ As a consequence, thermal $\mathrm{SiO}_{2}$ is currently only applied in the manufacturing of high-efficiency solar cells in which low impurity $c$-Si wafers are employed. ${ }^{5}$

Silicon nitride $\left(a-\mathrm{SiN}_{x}: \mathrm{H}\right)$ is currently the industry standard for surface passivation of $c$-Si solar cells. Effective surface recombination velocities as low as 6 and $15 \mathrm{~cm} / \mathrm{s}$ have been reported on $1.5 \Omega \mathrm{cm} n$-type and $1.5 \Omega \mathrm{cm} p$-type $c$-Si, respectively. ${ }^{6,7}$ The surface passivation mechanism of $a-\mathrm{SiN}_{x}: \mathrm{H}$ is mainly based on field-effect passivation induced by the high positive fixed charge density in $a-\mathrm{SiN}_{x}: \mathrm{H}$ films $\left(\sim 10^{12} \mathrm{~cm}^{-2}\right){ }^{8}$ The positive fixed charge density is particularly beneficial for the passivation of highly doped $n$-type $c$-Si because the minority carriers (i.e., the holes) are effec- 
tively shielded from the $c$-Si surface. On the other hand, the high positive fixed charge density can be detrimental for surface passivation of highly doped $p$-type $c$-Si surfaces because such a high positive fixed charge density increases the minority electron concentration at a highly doped $p$-type $c$-Si surface and consequently increases the recombination rate. ${ }^{9}$ Moreover, the high positive fixed charge density of $a-\mathrm{SiN}_{x}: \mathrm{H}$ can induce a parasitic shunting when applied at the rear of a $p$-type solar cell. ${ }^{10}$ Recently, it was, however, reported that it is possible to effectively passivate highly doped $p$-type $c$-Si surfaces by Si-rich $a$-SiN $\mathrm{S}_{x}: \mathrm{H}$ after a $4 \mathrm{~h}$ postdeposition annealing. The underlying mechanism in this case is still under investigation. ${ }^{11}$ Very recently, Mihailetchi et al. demonstrated that a nitric acid pretreatment could also significantly improve the level of surface passivation provided by $a-\mathrm{SiN}_{x}: \mathrm{H}$ on highly $p$-doped $c$-Si emitters. ${ }^{12}$

Amorphous silicon $(a-\mathrm{Si}: \mathrm{H})$ is the third material that is used in industry for surface passivation of $c$-Si. Films of $a-\mathrm{Si}: \mathrm{H}$ are employed in the heterojunction with intrinsic thin film (HIT) $c$-Si solar cell design of Sanyo. ${ }^{13}$ In HIT cells the $p-n$ junction is not formed by conventional dopant diffusion but by the deposition of a doped $a-\mathrm{Si}: \mathrm{H}$ film on a lightly doped $c$-Si wafer. An ultrathin intrinsic $a$-Si: $\mathrm{H}$ film between the $c$-Si and the doped $a-\mathrm{Si}: \mathrm{H}$ film effectively passivates the $c$-Si surface and consequently exceptionally high opencircuit voltages in excess of $700 \mathrm{mV}$ can be obtained by HIT solar cells. ${ }^{13}$ The good surface passivation by $a-\mathrm{Si}: \mathrm{H}$ can mainly be attributed to the excellent electrical quality of the interface between $c$-Si and the $a$-Si:H film. ${ }^{14,15}$ Additionally field-effect passivation plays a role as a result from the amphoteric nature of the Si dangling bond defects. ${ }^{14,15} a-\mathrm{Si}: \mathrm{H}$ has also successfully been applied for surface passivation on the rear side of diffused emitter $c$-Si solar cells. ${ }^{16}$ The main drawbacks associated with the use of $a-\mathrm{Si}: \mathrm{H}$ as surface passivation layer are the high absorption in the ultraviolet (UV) part of the solar spectrum and the low thermal stability of the $a$-Si:H films.

From the properties and performance of thermal $\mathrm{SiO}_{2}$, $a-\mathrm{SiN}_{x}: \mathrm{H}$, and $a-\mathrm{Si}: \mathrm{H}$, it is clear that there is still interest in alternative surface passivation layers for $c$-Si solar cells. A material that recently gained interest for $c$-Si surface passivation is the amorphous aluminum oxide $\left(\mathrm{Al}_{2} \mathrm{O}_{3}\right)$. Already in the late $1980 \mathrm{~s}, \mathrm{Al}_{2} \mathrm{O}_{3}$ was applied for $c$-Si surface passivation in metal-insulator-semiconductor (MIS) solar cells by Hezel and Jaeger. ${ }^{8}$ They demonstrated that $\mathrm{Al}_{2} \mathrm{O}_{3}$ could provide a reasonable level of surface passivation with an effective surface recombination velocity of $\sim 200 \mathrm{~cm} / \mathrm{s}$ on $2 \Omega \mathrm{cm} p$-type $c$-Si. The $c$-Si surface passivation was explained by a relatively low midgap interface defect density of $\sim 1 \times 10^{11} \mathrm{eV}^{-1} \mathrm{~cm}^{-2}$ and a negative fixed charge density of $\sim 3 \times 10^{12} \mathrm{~cm}^{-2}$. The interface defect density of the $c-\mathrm{Si} / \mathrm{Al}_{2} \mathrm{O}_{3}$ system was also found to be unaffected by UV radiation, ${ }^{8}$ in contrast to the strong increase in the interface defect density observed under the UV exposure of both $a-\mathrm{SiN}_{x}: \mathrm{H}$ and thermal $\mathrm{SiO}_{2}$ on $c-\mathrm{Si}^{8,17-19}$ As a matter of fact, the negative fixed charge density in $\mathrm{Al}_{2} \mathrm{O}_{3}$ was even observed to increase during UV exposure due to the photoninduced electron injection. Hence, the UV exposure improved the field-effect passivation provided by the $\mathrm{Al}_{2} \mathrm{O}_{3}$ film. ${ }^{8}$ Recently $\mathrm{Al}_{2} \mathrm{O}_{3}$ was reinvestigated as surface passivation layer, now with the $\mathrm{Al}_{2} \mathrm{O}_{3}$ synthesized by atomic layer deposition (ALD). Agostinelli et al. and Hoex et al. demonstrated that $\mathrm{ALD} \mathrm{Al}_{2} \mathrm{O}_{3}$ can provide an excellent level of surface passivation on $p$-type $c$-Si with effective surface recombination velocities close to $10 \mathrm{~cm} / \mathrm{s}$ on $2 \Omega \mathrm{cm} p$-type $c-\mathrm{Si}^{20,21}$

The aim of this paper is to give an overview of the properties of $\mathrm{ALD} \mathrm{Al}_{2} \mathrm{O}_{3}$ films to evaluate its potential for the application as surface passivation film in future $c$-Si solar cells. The recently reported data set is therefore extended by the results obtained for the $n$ - and $p$-type $c$-Si of various doping concentrations and data are presented for $\mathrm{Al}_{2} \mathrm{O}_{3}$ films deposited on two different ALD reactors as well as for both plasma-assisted and thermal ALD $\mathrm{Al}_{2} \mathrm{O}_{3}$. The level of surface passivation has been determined from techniques based on photoconductance, photoluminescence, and infrared emission and the specific merits of the techniques as well as the (good) agreement between their results are discussed. A key result of this work is that the field-effect passivation by the high negative fixed charge density in $\mathrm{Al}_{2} \mathrm{O}_{3}$ has been demonstrated experimentally and the consequences for the passivation of highly doped $n$ - and $p$-type $c$-Si will be addressed.

This paper is organized as follows: In Sec. II, the method of ALD for the deposition of $\mathrm{Al}_{2} \mathrm{O}_{3}$ is discussed as the technique is not yet common in the field of $c$-Si solar cell fabrication. In Sec. III, the experimental details are given and especially the three techniques employed to measure the level of surface passivation on $c$-Si are described in more detail (Sec. III C). Subsequently, the experimental results are presented in Sec. IV. The level of surface passivation on $n$-type (Sec. IV A) and $p$-type $c$-Si (Sec. IV B) passivated by $\mathrm{Al}_{2} \mathrm{O}_{3}$ will be presented for various doping concentrations. Finally, a brief comparison between plasma-assisted and thermal ALD $\mathrm{Al}_{2} \mathrm{O}_{3}$ films is presented for low resistivity $p$-type $c$-Si (Sec. IV C). The conclusions of the work are described in Sec. V. In the Appendix, the difference observed between the effective lifetimes determined from photoconductance and photoluminescence for nearly intrinsic $n$-type $c$-Si will be addressed.

\section{ATOMIC LAYER DEPOSITION OF $\mathrm{Al}_{2} \mathrm{O}_{3}$}

ALD is a chemical vapor deposition-like method in which the deposition is controlled at the atomic level by self-limiting surface reactions. The substrate surface is alternately exposed to gas phase precursors which react with the surface species until the surface is saturated. After such a self-limiting half-reaction, the reactor is purged and/or pumped down to remove the reactants and the reaction products from the reactor such that the next half-reaction can be started. By carrying out these half reactions in a cyclic manner, ultrathin films can be synthesized with precise thickness control, good uniformity over large substrates, and with an excellent conformality on three-dimensional surface topologies. The most common ALD process is the deposition of $\mathrm{Al}_{2} \mathrm{O}_{3}$ by alternating exposures of $\mathrm{Al}\left(\mathrm{CH}_{3}\right)_{3}$ and $\mathrm{H}_{2} \mathrm{O}$. ${ }^{22}$ In addition to $\mathrm{H}_{2} \mathrm{O}$, also other oxidation sources can be employed, such as $\mathrm{O}_{3}$ and an $\mathrm{O}_{2}$ plasma. When an $\mathrm{O}_{2}$ plasma is 


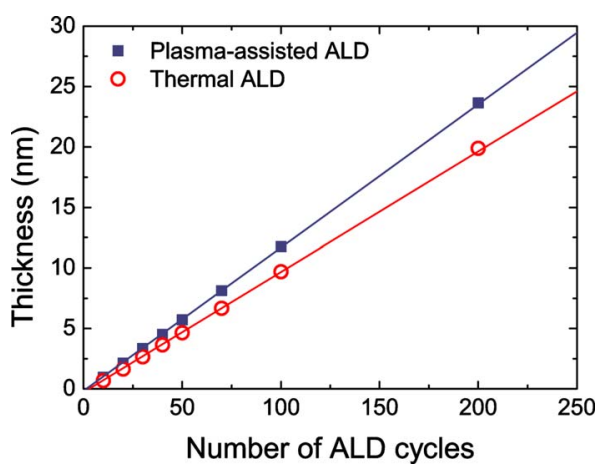

FIG. 1. (Color online) $\mathrm{Al}_{2} \mathrm{O}_{3}$ thickness as a function of the number of cycles for plasma-assisted ALD and thermal ALD. The thickness of the $\mathrm{Al}_{2} \mathrm{O}_{3}$ films was determined by in situ spectroscopic ellipsometry. Both films were grown at a substrate temperature of $200{ }^{\circ} \mathrm{C}$.

used, the method is referred to as plasma-enhanced or plasma-assisted ALD, compared to thermal ALD when $\mathrm{H}_{2} \mathrm{O}$ or $\mathrm{O}_{3}$ are employed.

The fact that the ALD process allows the deposition of thin $\mathrm{Al}_{2} \mathrm{O}_{3}$ films with precise thickness control is illustrated in Fig. 1. In this figure, it is shown that the $\mathrm{Al}_{2} \mathrm{O}_{3}$ film thickness scales linear with the number of ALD cycles for both the thermal and the plasma-assisted ALD process. Both films were synthesized in the same ALD reactor and at the same substrate temperature of $200{ }^{\circ} \mathrm{C}$. The slope of the film thickness as a function of the number of ALD cycles defines the so-called growth per cycle (GPC) of the ALD process. The GPC of $0.13 \mathrm{~nm} /$ cycle for the $\mathrm{Al}_{2} \mathrm{O}_{3}$ synthesized by plasmaassisted ALD is significantly higher than the GPC of 0.10 $\mathrm{nm} /$ cycle for the $\mathrm{Al}_{2} \mathrm{O}_{3}$ synthesized by thermal ALD. It is well known that the GPC of $\mathrm{Al}_{2} \mathrm{O}_{3}$ deposition can be different when different oxidation sources (e.g., $\mathrm{H}_{2} \mathrm{O}, \mathrm{O}_{3}$, or $\mathrm{O}_{2}$ plasma) are used, even though the processes are all truly ALD with saturated half-reactions. ${ }^{23,24}$ The material properties of the $\mathrm{Al}_{2} \mathrm{O}_{3}$ films in Fig. 1 as synthesized by plasmaassisted and thermal ALD were studied in detail and reported in the literature. ${ }^{24}$ Briefly, the structural material properties of the $\mathrm{Al}_{2} \mathrm{O}_{3}$ films synthesized by thermal and plasmaassisted ALD are very similar for substrate temperatures ranging from 200 to $300{ }^{\circ} \mathrm{C}$. The films are stoichiometric of composition $([\mathrm{O}] /[\mathrm{Al}]=1.5)$ and the hydrogen content $[\mathrm{H}]$ is typically $\sim 2$ and $\sim 1$ at. $\%$ for films synthesized at 200 and $300{ }^{\circ} \mathrm{C}$, respectively. Figure 2 shows the thickness distribution of an $\mathrm{Al}_{2} \mathrm{O}_{3}$ film synthesized by plasma-assisted ALD on a $200 \mathrm{~mm}$ wafer. With spectroscopic ellipsometry, the thickness was sampled at 300 points. The thickness decreases from $79.8 \mathrm{~nm}$ in the middle of the wafer to $78.6 \mathrm{~nm}$ at $1 \mathrm{~cm}$ from the edge of the wafer indicating a good thickness uniformity. In another study it was demonstrated that the plasma-assisted ALD process of $\mathrm{Al}_{2} \mathrm{O}_{3}$ yields an excellent conformality on high aspect ratio structures with an aspect ratio of $\sim 8$. $^{24}$

\section{EXPERIMENTAL DETAILS}

\section{A. ALD reactors}

The experiments reported in this paper were conducted in a laboratory-scale open-load reactor (ALD-I, home built $)^{25}$

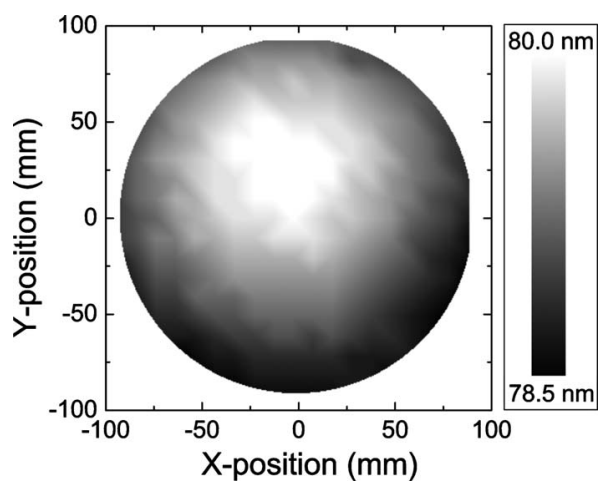

FIG. 2. $\mathrm{Al}_{2} \mathrm{O}_{3}$ thickness uniformity on a $200 \mathrm{~mm}$ diameter wafer as determined by spectroscopic ellipsometry. 300 data points were measured over the wafer up to a distance of $1 \mathrm{~cm}$ from the wafer edge. The $\mathrm{Al}_{2} \mathrm{O}_{3}$ film was synthesized by plasma-assisted ALD at the FlexAL reactor.

and in a commercially available reactor $\left(\right.$ FlexAL ${ }^{\mathrm{TM}}$, Oxford Instruments Plasma Technology) with a loadlock system. ${ }^{26}$ Both systems are equipped with a remote inductively coupled plasma source located above the wafer for plasmaassisted ALD. The ALD-I and FlexAL reactor are capable of handling wafers up to 100 and $200 \mathrm{~mm}$, respectively. The FlexAL reactor is equipped with multiple precursor pods and it can be used both for plasma-assisted and thermal ALD processes. Both reactors have optical viewports that enable in situ monitoring of the film growth by, e.g., spectroscopic ellipsometry. ${ }^{24}$ Other in situ diagnostic techniques have been fitted as well. ${ }^{27}$

In the current study, the $\mathrm{Al}_{2} \mathrm{O}_{3}$ films were deposited at $200{ }^{\circ} \mathrm{C}$ unless indicated otherwise. The precursor doses and exposure times were chosen such that all films were deposited under saturated self-limiting conditions. ${ }^{24}$ A typical plasma-assisted ALD cycle at the FlexAL reactor consisted of a $20 \mathrm{~ms}$ injection of $\mathrm{Al}\left(\mathrm{CH}_{3}\right)_{3}$ vapor followed by a $1.5 \mathrm{~s}$ purging with $\mathrm{O}_{2}$. Subsequently a $400 \mathrm{~W} \mathrm{O}_{2}$ plasma was ignited for $2 \mathrm{~s}$ followed by a $0.5 \mathrm{~s}$ purging with $\mathrm{O}_{2}$. Consequently, the ALD cycle time for plasma-assisted ALD on the FlexAL reactor was typically $4 \mathrm{~s}$. A thermal ALD cycle at the FlexAL reactor consisted of a $20 \mathrm{~ms}$ injection of $\mathrm{Al}\left(\mathrm{CH}_{3}\right)_{3}$ vapor followed by a 3 s Ar purge. The oxidation step consisted of a $240 \mathrm{~ms}$ injection of $\mathrm{H}_{2} \mathrm{O}$ vapor followed by a 12 s purge with Ar resulting in an ALD cycle time of $16 \mathrm{~s}$. The ALD process in the ALD-I reactor was not optimized with respect to cycle time and it consisted of five consecutive $\mathrm{Al}\left(\mathrm{CH}_{3}\right)_{3}$ dosings, $2 \mathrm{~s}$ Ar purging, and $2 \mathrm{~s} 100 \mathrm{~W} \mathrm{O}_{2}$ plasma exposure. This resulted in a total ALD cycle time of $22 \mathrm{~s}$.

For the surface passivation experiments, H-terminated $c$-Si wafers (see Sec. III C) were loaded in the reactor and preheated at the deposition temperature for $5 \mathrm{~min}$ before the start of the ALD process. Typically 50-255 ALD cycles were carried out resulting in $\mathrm{Al}_{2} \mathrm{O}_{3}$ films with a thickness of 7-30 $\mathrm{nm}$ as was monitored by in situ spectroscopic ellipsometry. For the lifetime measurements the $c$-Si wafers were coated at both sides. To do so, the wafer was turned over after the ALD of the $\mathrm{Al}_{2} \mathrm{O}_{3}$ film on the front side. Subsequently the sample was reloaded in the reactor without additional cleaning steps and an identical $\mathrm{Al}_{2} \mathrm{O}_{3}$ film was deposited at the rear side of the wafer. This resulted in symmetrically coated 


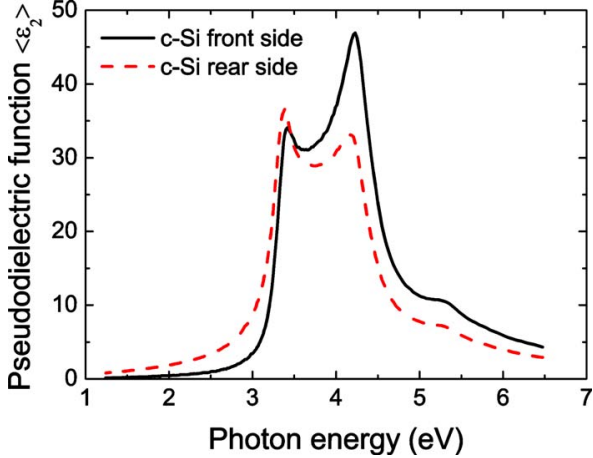

FIG. 3. (Color online) Imaginary part of the pseudodielectric function $\left\langle\varepsilon_{2}\right\rangle$ of the front and rear side of a $c$-Si wafer as measured before the deposition of the $\mathrm{Al}_{2} \mathrm{O}_{3}$ film on both wafer sides. The difference between the two dielectric functions can be explained by the formation of native oxide on the rear side of the $c$-Si wafer during the period that an $\mathrm{Al}_{2} \mathrm{O}_{3}$ film was synthesized by plasma-assisted ALD on the front side. For the surface passivation experiments, the formation of this native oxide on the rear side was avoided through the usage of a Si carrier wafer instead of placing the wafers directly on the reactor's substrate stage.

$c$-Si wafers. For the depositions in the FlexAL reactor, it was found that a $c$-Si carrier wafer was necessary to protect the uncoated rear side of the $c$-Si wafer during the deposition of the $\mathrm{Al}_{2} \mathrm{O}_{3}$ film on the front side (see also Sec. III B). For the ALD-I reactor this was not necessary. The difference can most likely be attributed to differences in the design and materials used for the substrate stages in the two reactors.

\section{B. In situ spectroscopic ellipsometry}

The $\mathrm{Al}_{2} \mathrm{O}_{3}$ ALD processes were monitored by in situ spectroscopic ellipsometry measurements in the 1.24-6.50 eV photon energy range (J.A. Woollam M2000-D ellipsometer). Measurements were taken both prior to and during the $\mathrm{Al}_{2} \mathrm{O}_{3}$ deposition process. Spectroscopic ellipsometry measures the change in polarization of the reflected light expressed in the two ellipsometric angles $\Psi$ and $\Delta .{ }^{28}$ From the ellipsometric angles a pseudodielectric function $\langle\varepsilon\rangle=\left\langle\varepsilon_{1}\right\rangle$ $+i\left\langle\varepsilon_{2}\right\rangle$ can be calculated for the sample by assuming that $\Psi$ and $\Delta$ arise from the reflection on a planar interface between air and a semi-infinite material with a pseudodielectric function $\langle\varepsilon\rangle .{ }^{28}$ The imaginary part $\left\langle\varepsilon_{2}\right\rangle$ of a $c$-Si substrate is extremely sensitive to the presence of native oxide or surface roughness at the $c$-Si surface, especially at the $c$-Si bulk critical point energy of $4.2 \mathrm{eV}^{29}$ Therefore, the $\langle\varepsilon\rangle$ of $c$-Si was used to evaluate the condition of the $c$-Si surfaces (both for the front and rear sides of the wafer) prior to the deposition of the $\mathrm{Al}_{2} \mathrm{O}_{3}$ film.

Figure 3 shows $\left\langle\varepsilon_{2}\right\rangle$ for a $c$-Si wafer as measured at both surfaces prior to the deposition of $\mathrm{Al}_{2} \mathrm{O}_{3}$ film. For the front side of the wafer, the $\left\langle\varepsilon_{2}\right\rangle$ value of 47 at the $E_{2}$ bulk critical point energy indicates a clean H-terminated $c$-Si surface. ${ }^{29}$ For the rear side of the wafer, the $\left\langle\varepsilon_{2}\right\rangle$ value at the $E_{2}$ bulk critical point energy is only 33 . This significantly lower $\left\langle\varepsilon_{2}\right\rangle$ value can be attributed to the presence of a native oxide on the rear side of the wafer, and from model calculations the presence of a $2.2 \mathrm{~nm}$ native oxide film on the $c$-Si could be derived. It was experimentally found that the native oxide formed at the rear side of the $c$-Si wafer during ALD on the front side of the wafer had a detrimental effect on the level of surface passivation obtained. The formation of such a native oxide on the rear surface during ALD on the front side of the wafer was only observed for the FlexAL reactor and could be prevented by the application of a carrier wafer. Therefore, a carrier wafer was used for all surface passivation experiments carried out in the FlexAL reactor, as mentioned in Sec. III A. With spectroscopic ellipsometry it was verified that all the results reported in this paper were obtained on "clean" $\mathrm{H}$-terminated front and rear surfaces. The preparation of these surfaces is described in Sec. III C.

The ellipsometry spectra of the wafers as obtained during the $\mathrm{Al}_{2} \mathrm{O}_{3}$ deposition process were analyzed by a two layer optical model. This model consisted of a substrate with its optical properties defined by the measurement prior to deposition, and an $\mathrm{Al}_{2} \mathrm{O}_{3}$ film with the optical properties described by a Cauchy model. ${ }^{28}$ The typical refractive index for the $\mathrm{Al}_{2} \mathrm{O}_{3}$ films was in the range of $1.60-1.65$ at a photon energy of $2 \mathrm{eV}$ and the $\mathrm{Al}_{2} \mathrm{O}_{3}$ films did not show any absorption in the photon energy range investigated.

\section{C. $c$-Si surface passivation}

The surface passivation induced by the $\mathrm{Al}_{2} \mathrm{O}_{3}$ films was tested on double-side polished FZ $p$-type and $n$-type $c$-Si substrates of various doping concentrations. The $c$-Si substrates were cleaned using a conventional RCA1 and RCA2 clean and received a final treatment in diluted HF $(1 \%)$ prior to deposition. This treatment results in a $\mathrm{H}$-terminated $c$-Si surface which remains stable in open air for typically 15 min. ${ }^{30,31}$ After being symmetrically coated with $\mathrm{Al}_{2} \mathrm{O}_{3}$, the $c$-Si wafers were annealed at $425{ }^{\circ} \mathrm{C}$ for $30 \mathrm{~min}$ in a $N_{2}$ atmosphere. As reported in previous publications, this postdeposition annealing is found to be essential for obtaining the high levels of surface passivation reported. ${ }^{21,32}$

The injection level dependent effective lifetime of the charge carriers in the symmetrically passivated $c$-Si wafer was determined by two different techniques. In the first technique, the injection level dependence of the effective lifetime was determined by photoconductance (Sinton Consulting WCT-100 lifetime tester). ${ }^{33}$ The effective lifetime of a passivated $c$-Si wafer was determined over a broad injection level range by measuring the excess conductance (photoconductance) by a contactless inductively coupled coil during a short $[\sim 10 \mu \mathrm{s}$, photoconductance decay (PCD)] or long [ 2 ms, quasi-steady-state photoconductance (QSSPC)] light flash. ${ }^{33}$ As all charge carriers contribute equally to the excess conductance of the $c$-Si wafer, the photoconductance technique is sensitive to carrier trapping or depletion region modulation. ${ }^{34,35}$ Both carrier trapping and depletion region modulations, if not correctly accounted for, lead to a strong increase in the apparent effective lifetime for low injection levels (typically $10^{13}-10^{15} \mathrm{~cm}^{-3}$ ). As a consequence, the level of surface passivation cannot be determined from photoconductance at low injection levels for wafers with a high trap density and/or a depletion region at the $c$-Si surface.

To assess the level of surface passivation at lower injection levels, a second technique, quasi-steady-state photoluminescence, was employed to determine the injection level 
dependent effective lifetimes. With this technique the injection level dependent effective lifetime is determined from the steady-state radiative recombination of charge carriers under steady-state illumination. ${ }^{36}$ The effective lifetime is calculated from the photoluminescence intensity using the selfconsistent calibration method proposed by Trupke et al. ${ }^{37} \mathrm{As}$ the photoluminescence signal is proportional to the electronhole product, the measurements are basically unaffected by carrier trapping and depletion region modulation. Consequently, the effective lifetime can be determined at lower injection levels than for the photoconductance technique. It has, for example, been shown by Trupke et al. that effective lifetimes could accurately be determined down to the injection levels of $10^{9} \mathrm{~cm}^{-3} .{ }^{36}$ This study also demonstrated that photoluminescence and photoconductance show a good agreement in the injection level range studied by the photoconductance measurements. ${ }^{36}$

The uniformity of surface passivation was determined by the infrared lifetime mapping method. ${ }^{38}$ The effective lifetime of the charge carriers was determined from the infrared emission by the free carriers during steady-state illumination. The infrared emission is proportional to the total carrier concentration and, hence, is sensitive to carrier trapping and depletion region modulation. As a matter of fact, the sensitivity for carrier trapping is exploited when the infrared lifetime mapping technique is used for the mapping of the trap density of (multi)crystalline Si wafers. ${ }^{39}$

All three techniques measure the effective lifetime $\tau_{\text {eff }}$ for symmetrically passivated $c$-Si wafers from which the level of surface passivation can be obtained. As will be demonstrated in Sec. IV, the values of $\tau_{\text {eff }}$ derived from the three techniques show good agreement in all cases reported apart from the results obtained for nearly intrinsic $c$-Si wafers. As discussed in the Appendix, under these conditions the results obtained by the photoconductance technique suffer from an artifact as recently also reported by McIntosh et al. ${ }^{40}$

The effective surface recombination velocity $S_{\text {eff }}$ can be calculated from $\tau_{\text {eff }}$ by the expression

$$
\frac{1}{\tau_{\text {eff }}}=\frac{1}{\tau_{\text {bulk }}}+\frac{2 S_{\text {eff }}}{d},
$$

with $\tau_{\text {bulk }}$ being the $c$-Si bulk lifetime and $d$ the wafer thickness. As high purity FZ $c$-Si with a moderate doping level was used in this study, no empirically determined upper level for the intrinsic $c$-Si bulk lifetime (e.g., due to the Auger recombination) was assumed throughout this paper. Hence the bulk lifetime was set to infinity and the values of the effective surface recombination velocity $S_{\text {eff,max }}$ reported in this work should be considered as upper limits.

\section{Capacitance voltage and corona charging experiments}

Capacitance-voltage $(C-V)$ measurements on metaloxide-semiconductor (MOS) structures were carried out on selected samples. The $\mathrm{Al}_{2} \mathrm{O}_{3}$ films, deposited on HF-dipped 20-30 $\Omega \mathrm{cm} p$-type $c$-Si wafers, were annealed for $30 \mathrm{~min}$ at $425{ }^{\circ} \mathrm{C}$ in $N_{2}$. Subsequently $\mathrm{Al}$ dots with an area of
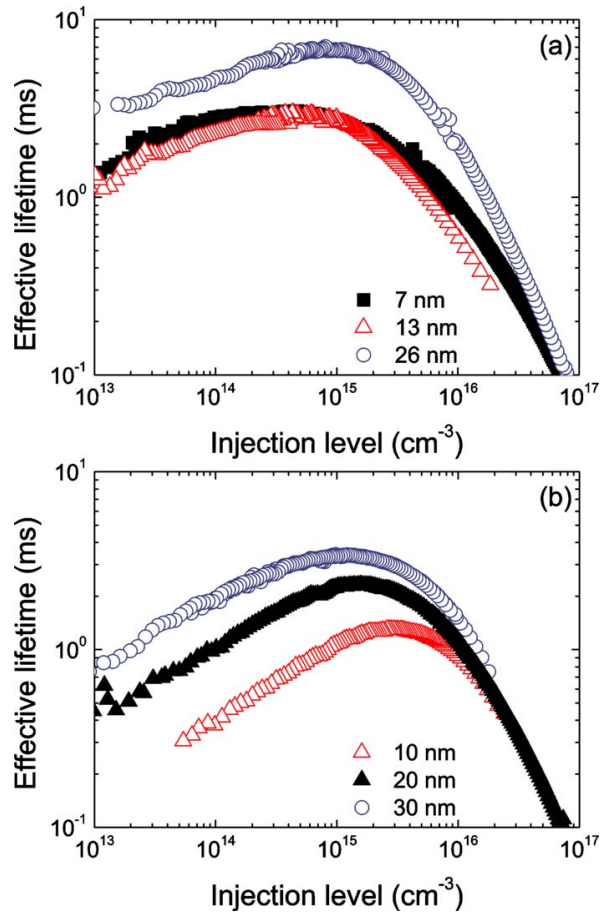

FIG. 4. (Color online) Injection level dependent effective lifetimes of $n$-type $c$-Si $(1.9 \Omega \mathrm{cm},\langle 100\rangle, 275 \mu \mathrm{m})$ wafers symmetrically passivated by $\mathrm{Al}_{2} \mathrm{O}_{3}$ as measured by photoconductance. The $\mathrm{Al}_{2} \mathrm{O}_{3}$ films, with thicknesses ranging from 7 to $30 \mathrm{~nm}$, were synthesized by plasma-assisted ALD at (a) the ALD-I reactor and (b) the FlexAL reactor. All films were deposited at a substrate temperature of $200{ }^{\circ} \mathrm{C}$ and with an $\mathrm{O}_{2}$ plasma exposure of $2 \mathrm{~s}$ with the only exception of the $20 \mathrm{~nm}$ film deposited at the FlexAL reactor. For this film the substrate temperature was $300{ }^{\circ} \mathrm{C}$ and the plasma exposure time $4 \mathrm{~s}$.

$\sim 1 \mathrm{~mm}^{2}$ were sputtered on the $\mathrm{Al}_{2} \mathrm{O}_{3}$ film. The $C$ - $V$ curves were measured at $10 \mathrm{kHz}$ with an HP4275A multifrequency LCR meter. ${ }^{24}$

Corona charging experiments were conducted to study the impact of the negative fixed charge density in the $\mathrm{Al}_{2} \mathrm{O}_{3}$ films on the level of $c$-Si surface passivation. By applying a high electric field at a tungsten needle, air particles and molecules were ionized in a corona chamber and positive ions were created. ${ }^{41,42}$ The positive charges, mainly consisting of $\left(\mathrm{H}_{2} \mathrm{O}\right)_{n} \mathrm{H}^{+}$ions, were deposited in small amounts on one side of a symmetrically passivated $c$-Si wafer. ${ }^{43}$ Subsequently the surface potential was determined by a vibrating Kelvin probe and the positive surface charge density was calculated using the dielectric constant derived from the $C-V$ measurements and the film thickness obtained by spectroscopic ellipsometry. Simultaneously the effective lifetime of the passivated $c$-Si wafer was determined by the infrared lifetime mapping. This procedure was repeated multiple times for different positive surface charge densities up to a maximum positive surface charge density of $2 \times 10^{13} \mathrm{~cm}^{-2}$.

\section{RESULTS AND DISCUSSION}

\section{A. $n$-type $c$-Si passivated by plasma-assisted ALD $\mathrm{Al}_{2} \mathrm{O}_{3}$}

The level of surface passivation was tested on $n$-type $c$-Si wafers $(1.9 \Omega \mathrm{cm}\langle 100\rangle)$ with a thickness of $275 \mu \mathrm{m}$. In Fig. 4, the effective lifetimes are shown for the $c$-Si wa- 
fers passivated by $\mathrm{Al}_{2} \mathrm{O}_{3}$ synthesized on the ALD-I and FlexAL reactor. The results obtained on the ALD-I reactor were reported previously. ${ }^{21}$ From Fig. 4 , it is clear that lifetimes in excess of $3 \mathrm{~ms}$ were obtained on both reactors. The $7 \mathrm{~nm}$ and $13 \mathrm{~nm}$ thick $\mathrm{Al}_{2} \mathrm{O}_{3}$ films synthesized on the ALD-I reactor had a better level of surface passivation than the 10 and $20 \mathrm{~nm}$ thick $\mathrm{Al}_{2} \mathrm{O}_{3}$ films synthesized on the FlexAL reactor. For the $\mathrm{Al}_{2} \mathrm{O}_{3}$ films synthesized on the FlexAL reactor, the level of surface passivation clearly increases for increasing film thickness up to $30 \mathrm{~nm}$ which is not uncommon for thin films used for surface passivation on $c$-Si. When $a-\mathrm{Si}: \mathrm{H}, a-\mathrm{SiN}_{x}: \mathrm{H}$, and $a-\mathrm{SiC}_{x}: \mathrm{H}$ are used to passivate $c-\mathrm{Si}$, it is generally found that the level of surface passivation increases with film thickness and typically only saturates for films with a thickness $>20 \mathrm{~nm} .^{44-46}$ The small difference between the results obtained on the ALD-I and FlexAL reactor can most probably be related to a small difference in the negative fixed charge density in the $\mathrm{Al}_{2} \mathrm{O}_{3}$ films, as will be discussed in Sec. IV C. The highest lifetimes obtained on the ALD-I and FlexAL reactor correspond to $S_{\text {eff,max }}$ values of 2 and $4 \mathrm{~cm} / \mathrm{s}$, respectively.

The $\mathrm{Al}_{2} \mathrm{O}_{3}$ films deposited on the ALD-I reactor and the 10 and $30 \mathrm{~nm}$ film deposited at the FlexAL reactor were all grown using a substrate temperature of $200{ }^{\circ} \mathrm{C}$ and a plasma exposure step of $2 \mathrm{~s}$. As mentioned in Sec. II, the asdeposited material properties of the $\mathrm{Al}_{2} \mathrm{O}_{3}$ films deposited at a substrate temperature of 200 and $300{ }^{\circ} \mathrm{C}$ were quite similar. ${ }^{24}$ Such a similarity apparently also holds for the passivation performance of the films deposited at 200 and $300{ }^{\circ} \mathrm{C}$. The $20 \mathrm{~nm} \mathrm{Al}_{2} \mathrm{O}_{3}$ film deposited on the FlexAL reactor at a substrate temperature of $300{ }^{\circ} \mathrm{C}$ and with a plasma exposure time of $4 \mathrm{~s}$ perfectly fits the trend of the $200{ }^{\circ} \mathrm{C}$ deposited films. This indicates that the level of surface passivation is not very dependent on the substrate temperature when in the range of $200-300{ }^{\circ} \mathrm{C}$. In the remainder of the paper, all results reported are obtained for $\mathrm{Al}_{2} \mathrm{O}_{3}$ films synthesized at a substrate temperature of $200{ }^{\circ} \mathrm{C}$ and a plasma exposure time of $2 \mathrm{~s} \mathrm{O}_{2}$.

As mentioned in the Introduction, the high negative fixed charge density in the $\mathrm{Al}_{2} \mathrm{O}_{3}$ films provides field-effect passivation by electrostatically shielding electrons from the $c$-Si surface. This effect was experimentally demonstrated by depositing positive corona charges on the $\mathrm{Al}_{2} \mathrm{O}_{3}$ surface to compensate the negative fixed charge density in the $\mathrm{Al}_{2} \mathrm{O}_{3}$ film. A similar approach using negative corona charges was used by Glunz et al. and Dauwe et al. to study the positive fixed charge density in thermal $\mathrm{SiO}_{2}$ and $a-\mathrm{SiN}_{x}: \mathrm{H}$ films. ${ }^{41,42}$ The effective lifetime as a function of the positive-charge density $Q_{\text {corona }}$ deposited at the surface of the $\mathrm{Al}_{2} \mathrm{O}_{3}$ film in a corona chamber is shown in Fig. 5(a). Apart from a steady decline, which is most likely caused by too extensive handling of the $c$-Si wafer, the effective lifetime of the $c$-Si wafer is initially hardly affected by the positive-charge density deposited at the surface. The effective lifetime remains $>3 \mathrm{~ms}$ up to a positive $Q_{\text {corona }}$ of $1.0 \times 10^{13} \mathrm{~cm}^{-2}$. However, for a $Q_{\text {corona }}$ between $(1.2-1.4) \times 10^{13} \mathrm{~cm}^{-2}$ a strong decrease in the effective lifetime is observed. A minimal effective lifetime of $\sim 100 \mu \mathrm{s}$ is obtained for a positive $Q_{\text {corona }}$ of $1.3 \times 10^{13} \mathrm{~cm}^{-2}$. Consequently, the recombination rate at the
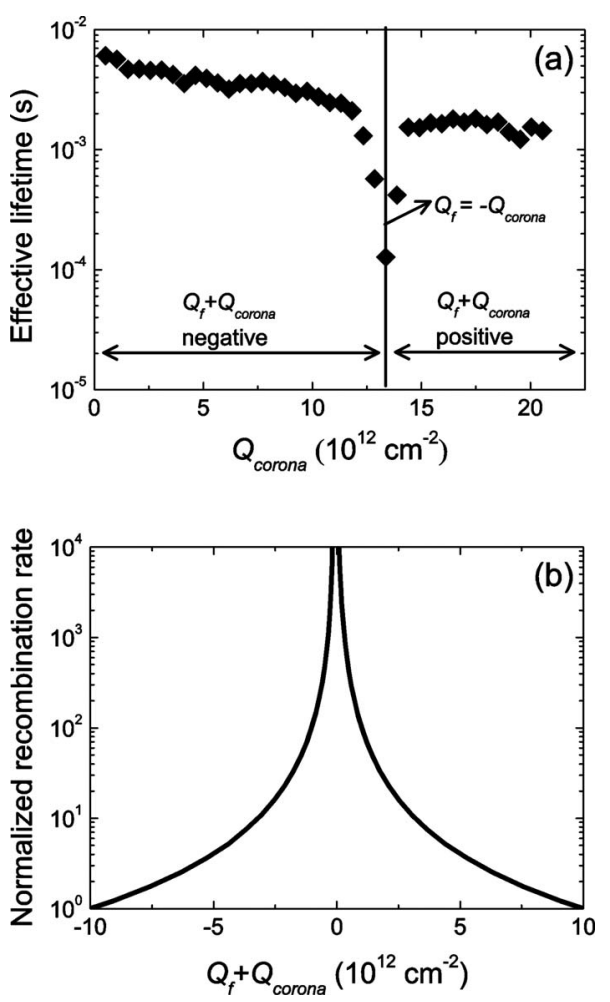

FIG. 5. (a) Effective lifetime of an $n$-type $c$-Si $(1.9 \Omega \mathrm{cm},\langle 100\rangle, 275 \mu \mathrm{m})$ wafer symmetrically passivated by a $26 \mathrm{~nm}$ thick $\mathrm{Al}_{2} \mathrm{O}_{3}$ film as a function of the positive-charge density $Q_{\text {corona }}$ at the surface. The effective lifetime was measured by infrared lifetime mapping at an injection level of $10^{14}-10^{15} \mathrm{~cm}^{-3}$. The film was deposited on the ALD-I reactor by plasmaassisted ALD (b) The recombination activity (in arbitrary units) at a $1.9 \Omega \mathrm{cm} n$-type $c$-Si surface as a function of the sum of $Q_{f}$ and $Q_{\text {corona }}$ estimated by model calculations without taking additional charge carrier creation by external illumination into account. The recombination rate was assumed to be governed by the concentration of minority carriers applying equal capture cross sections for electrons and holes at the $c$-Si surface. Consequently, for a $Q_{\text {corona }}<1.3 \times 10^{13} \mathrm{~cm}^{-2}$ the sum of $Q_{f}$ and $Q_{\text {corona }}$ is negative and for $Q_{\text {corona }}>1.3 \times 10^{13} \mathrm{~cm}^{-2}$ the sum is positive. The simulations were conducted with the software package PC1D (Ref. 47).

$c$-Si surface is maximized for a positive $Q_{\text {corona }}$ of 1.3 $\times 10^{13} \mathrm{~cm}^{-2}$. When the $Q_{\text {corona }}$ at the surface is further increased to $2 \times 10^{13} \mathrm{~cm}^{-2}$, the effective lifetime increases again to values close to $2 \mathrm{~ms}$.

In Fig. 5(b), the recombination rate at the surface of a $1.9 \Omega \mathrm{cm} \mathrm{n} n$-type $c$-Si is simulated as a function of the total charge density present at the $c$-Si surface without taking additional charge carrier creation by external illumination into account. These simulations were performed in the software package PC1D that solves the coupled nonlinear electron and hole transport equations in crystalline semiconductors numerically. ${ }^{47}$ For simplicity we have assumed identical capture cross sections for electrons and holes and consequently the recombination rate is governed by the minority carrier concentration at the $c$-Si surface. For zero charge density these minority carriers are the holes and electrons for $n$-type and $p$-type $c$-Si, respectively. However, for a high positivecharge density the holes are the minority carriers at the surface of both lightly doped $n$ - or $p$-type $c$-Si, and for a high negative-charge density the electrons are the minority carriers at the surface of both lightly doped $n$ - or $p$-type $c$-Si. ${ }^{41,48}$ From Fig. 5(b), we can see that the maximum recombination 
rate at the $c$-Si surface occurs when the sum of the $Q_{f}$ and $Q_{\text {corona }}$ is approximately zero. Hence, the minimum effective lifetime in Fig. 5(a) indicates the point at which the positive $Q_{\text {corona }}$ is balancing the negative $Q_{f}$ in the $\mathrm{Al}_{2} \mathrm{O}_{3}$ film. Consequently, we can estimate the negative fixed charge density present in this $26 \mathrm{~nm} \mathrm{Al} \mathrm{O}_{3}$ film at $1.3 \times 10^{13} \mathrm{~cm}^{-2}$.

From the simulation results in Fig. 5(b), we can also obtain some more insights into the field-effect passivation of $c$-Si. If the fixed charge density is sufficiently large (e.g., $Q_{f}>5 \times 10^{11} \mathrm{~cm}^{-2}$ ), the recombination rate approximately scales with $1 / Q_{f}^{2}$ on lightly doped $c$-Si surfaces, irrespective of the polarity of the fixed charge density. Hence, the fixed charge density $>10^{13} \mathrm{~cm}^{-2}$ measured for the $26 \mathrm{~nm} \mathrm{Al} \mathrm{O}_{3}$ film implies that the field-effect passivation by this $\mathrm{Al}_{2} \mathrm{O}_{3}$ film is two orders of magnitude stronger than for a typical $a$-SiN $x$ : $\mathrm{H}$ film $\left(Q_{f}=\sim 10^{12} \mathrm{~cm}^{-2}\right)$ and up to four orders of magnitude stronger than a typical thermal $\mathrm{SiO}_{2}$ film $\left(Q_{f}\right.$ $\left.<10^{11} \mathrm{~cm}^{-2}\right){ }^{41,42}$ Moreover, Fig. 5(b) also clearly demonstrates that a high level of field-effect passivation can be obtained by the shielding of either electrons or holes from the $c$-Si surface. For the $1.9 \Omega n$-type $c$-Si wafer in Fig. 5, the level of field-effect passivation is independent of the polarity of the fixed charge density if $\left|Q_{f}\right|>5 \times 10^{11} \mathrm{~cm}^{-3}$. It is expected that a similar effect holds for $p$-type $c$-Si and hence, a good level of field-effect passivation can be obtained on lightly doped $n$ - or $p$-type $c$-Si by either dielectrics with a positive or negative $Q_{f}$ if the fixed charge density is sufficiently high. This explains why dielectrics with a high fixed charge density such as $a-\mathrm{SiN}_{x}: \mathrm{H}$ and $\mathrm{Al}_{2} \mathrm{O}_{3}$ can demonstrate a high level of surface passivation on both lightly doped $n$ - and $p$-type $c$-Si. ${ }^{6,21}$

The polarity of the fixed charge density is, however, of influence when considering the injection level dependence of the effective lifetime curves. The negative polarity of the fixed charge density in $\mathrm{Al}_{2} \mathrm{O}_{3}$ can provide an explanation of the injection level dependence of the effective lifetime for the passivated $n$-type $c$-Si wafers, as shown in Fig. 4 . The effective lifetime peaks at an injection level within the range of $(1-3) \times 10^{15} \mathrm{~cm}^{-3}$. At high injection levels $(>5$ $\times 10^{15} \mathrm{~cm}^{-3}$ ), the effective lifetime decreases because the Auger recombination in the bulk of the $c$-Si wafer dominates. $^{49}$ At lower injection levels the effective lifetime also decreases and this decrease is even more pronounced for the samples deposited in the FlexAL [Fig. 4(b)] reactor than for the samples deposited in the ALD-I reactor [Fig. 4(a)]. A similar injection level dependence of the effective lifetime was reported for $p$-type $c$-Si passivated by dielectrics with a positive fixed charge density such as thermal $\mathrm{SiO}_{2}$ and $a-\mathrm{SiN}_{x}: \mathrm{H}^{6,42}$ In this case, this injection level dependence was primarily attributed to bulk recombination in the depletion region that is formed by the shielding of holes from the $c$-Si surface. ${ }^{41,42}$ Consequently, the decrease of the effective lifetime at low injection levels for $n$-type $c$-Si wafers passivated by $\mathrm{Al}_{2} \mathrm{O}_{3}$ can most probably be attributed to bulk recombination losses in the depletion region near the $c$-Si surface induced by the negative fixed charge density in the $\mathrm{Al}_{2} \mathrm{O}_{3}$ film.

In addition to the lightly doped $n$-type $c$-Si wafers $(1.9 \Omega \mathrm{cm})$, nearly intrinsic $n$-type $c$-Si $(2 \mathrm{k} \Omega \mathrm{cm},\langle 111\rangle$

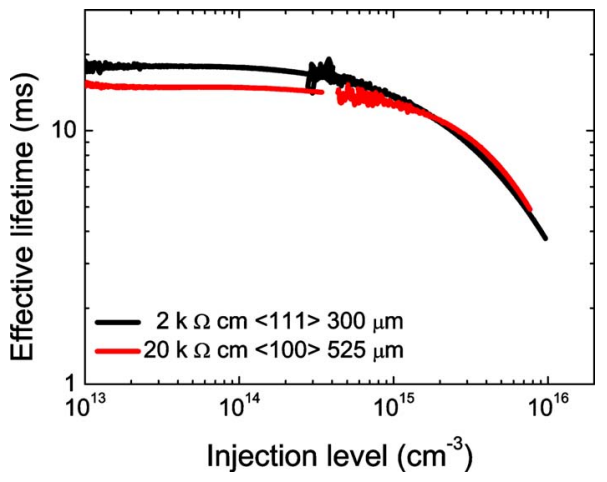

FIG. 6. (Color online) Injection level dependent effective lifetime of nearly intrinsic $n$-type $c$-Si wafers symmetrically passivated by a $30 \mathrm{~nm} \mathrm{Al}_{2} \mathrm{O}_{3}$ film synthesized by plasma-assisted ALD in the FlexAL. The effective lifetime was measured by quasi-steady-state photoluminescence.

and $20 \mathrm{k} \Omega \mathrm{cm},\langle 100\rangle$ ) wafers were passivated by $30 \mathrm{~nm}$ thick $\mathrm{Al}_{2} \mathrm{O}_{3}$ films synthesized by plasma-assisted ALD in the FlexAL reactor. The effective lifetime of these passivated high-resistivity wafers was measured by both the photoconductance and photoluminescence technique. Significant differences were observed for the effective lifetimes extracted from the photoconductance technique versus the photoluminescence technique. As discussed in the Appendix, these difference can most likely be attributed to the nonlinear calibration of the Sinton lifetimetester for high-resistivity $c$-Si wafers, as shown by McIntosch et al. ${ }^{40}$ Consequently, only effective lifetime curves extracted from photoluminescence are considered for passivated high-resistivity wafers in this section.

The injection level dependent lifetime determined from the quasi-steady-state photoluminescence technique is shown in Fig. 6. This figure reveals that lifetimes in excess of $18 \mathrm{~ms}$ can be obtained for $c$-Si wafers passivated by $\mathrm{Al}_{2} \mathrm{O}_{3}$. These are among the highest measured effective lifetimes for passivated $c$-Si wafers reported in the literature. Different from the results obtained on lightly-doped $n$-type $c$-Si, the injection level dependence of the effective lifetime for these high resistivity $c$-Si wafers is flat at low injection level, which is most probably related to the fact that these $c$-Si wafers are only lightly doped with a $\mathrm{P}$ density in the range of $10^{11}-10^{12} \mathrm{~cm}^{-3}$. Hence, an inversion layer at the $c$-Si surface can only form if the excess carrier density is lower than the bulk doping level of $10^{11}-10^{12} \mathrm{~cm}^{-3}$, which is below the detection limit of the photoluminescence technique for these high-resistivity $c$-Si wafers. The effective lifetimes obtained for these nearly intrinsic $c$-Si wafers unambiguously demonstrate that $S_{\text {eff,max }}$ values below $1 \mathrm{~cm} / \mathrm{s}$ can be obtained on $c$-Si passivated by ALD-grown $\mathrm{Al}_{2} \mathrm{O}_{3}$ films.

\section{B. p-type c-Si passivated by plasma-assisted ALD-grown $\mathrm{Al}_{2} \mathrm{O}_{3}$}

In Fig. 7, the results obtained on $p$-type $c$-Si (2.0 $\Omega \mathrm{cm}\langle 111\rangle)$ wafers with a thickness of $300 \mu \mathrm{m}$ are shown. Effective lifetimes in excess of $1 \mathrm{~ms}$ were obtained both for films deposited on the ALD-I and on the FlexAL system. The results obtained on the ALD-I reactor, which were already reported previously, ${ }^{21}$ reveal that the maximum 

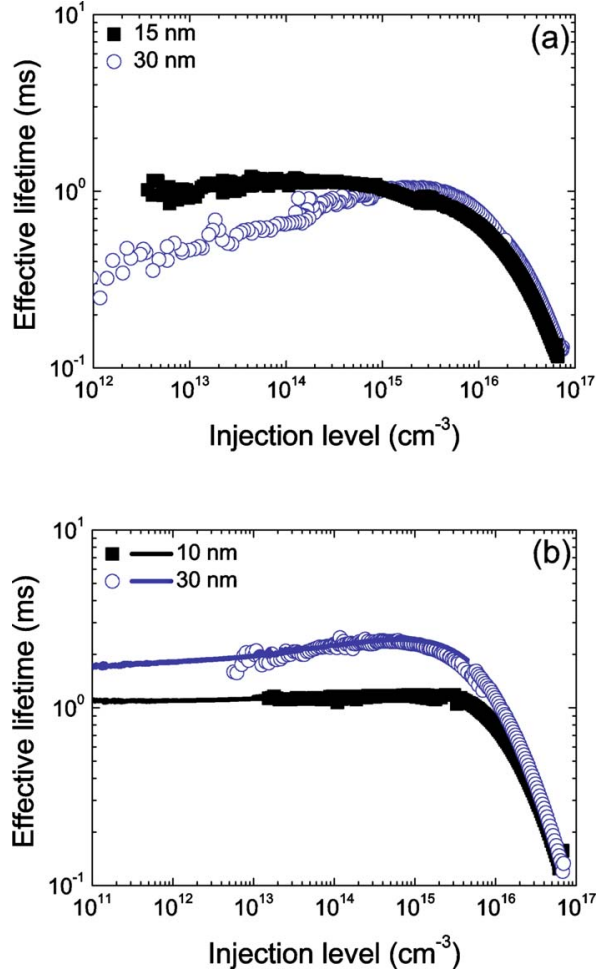

FIG. 7. (Color online) Injection level dependent effective lifetime of $p$-type $c$-Si $(2 \Omega \mathrm{cm},\langle 111\rangle, 300 \mu \mathrm{m})$ wafers symmetrically passivated by $\mathrm{Al}_{2} \mathrm{O}_{3}$ films synthesized by plasma-assisted ALD on (a) the ALD-I reactor and (b) the FlexAL reactor. The effective lifetime was measured by the photoconductance technique for all samples (symbols). For the samples deposited at the FlexAL reactor, the effective lifetime was also measured by quasisteady-state photoluminescence (solid lines)

effective lifetime of the $c$-Si wafers passivated by 15 and 30 $\mathrm{nm} \mathrm{Al}_{2} \mathrm{O}_{3}$ films is almost equal, i.e., $1.2 \mathrm{~ms}$. However, the injection level dependence of the effective lifetime is completely different for these $c$-Si wafers. This difference will be addressed in more detail below. For $\mathrm{Al}_{2} \mathrm{O}_{3}$ films deposited at the FlexAL, effective lifetimes of 1.2 and $2.5 \mathrm{~ms}$ were obtained for $c$-Si wafers passivated by 10 and $30 \mathrm{~nm}$ thick $\mathrm{Al}_{2} \mathrm{O}_{3}$ films, respectively. The latter value exceeds the results obtained on the ALD-I reactor and corresponds to a $S_{\text {eff,max }}$ of $6 \mathrm{~cm} / \mathrm{s}$. Once again it is observed that the level of surface passivation provided by a $30 \mathrm{~nm} \mathrm{Al}_{2} \mathrm{O}_{3}$ film is roughly a factor of 2 higher than the surface passivation provided by the $10 \mathrm{~nm} \mathrm{Al} \mathrm{O}_{3}$.

The uniformity of the surface passivation was determined by means of infrared lifetime mapping on $100 \mathrm{~mm}$ $c$-Si wafers. The results are shown in Fig. 8 for samples deposited at both the ALD-I and the FlexAL reactor. As expected the measured effective lifetimes are in good agreement with the values obtained from photoconductance. The uniformity of the surface passivation of the sample deposited on the ALD-I reactor was rather poor whereas the uniformity for the sample deposited on the FlexAL reactor was good. The effective lifetime of the $100 \mathrm{~mm} c$-Si wafer deposited in the FlexAL reactor is $>2 \mathrm{~ms}$ for the largest part of the wafer and it only decreases slightly at the edges.

In addition to the photoconductance measurements, the injection level dependence of the effective lifetime was also determined from quasi-steady-state photoluminescence mea-

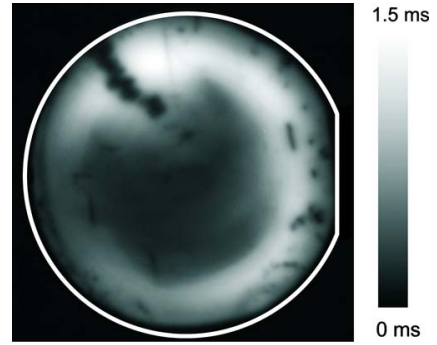

(a)

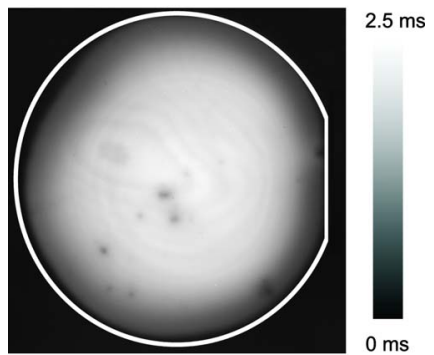

(b)

FIG. 8. (Color online) Infrared lifetime mapping of a $100 \mathrm{~mm}$ diameter $p$-type $c$-Si wafer $(2 \Omega \mathrm{cm},\langle 111\rangle, 300 \mu \mathrm{m})$ symmetrically passivated by a $30 \mathrm{~nm} \mathrm{Al}{ }_{2} \mathrm{O}_{3}$ film synthesized by plasma-assisted ALD on (a) the ALD-I reactor and (b) the FlexAL reactor. The effective lifetime was measured for an injection level of $(5-10) \times 10^{14} \mathrm{~cm}^{-3}$. The edge of the wafer has been indicated for clarity.

surements for the $c$-Si wafers passivated by $\mathrm{Al}_{2} \mathrm{O}_{3}$ films deposited on the FlexAL reactor. From Fig. 7(b), it can be observed that there is an excellent agreement between the effective lifetime determined by both techniques down to an injection level of $1 \times 10^{13} \mathrm{~cm}^{-3}$. This corroborates that the lifetime measurements by photoconductance on these $p$-type wafers were not affected by artifacts such as carrier trapping or depletion region modulation. The injection level dependence can therefore indeed be related to the surface passivation mechanism. ${ }^{35,50}$ The effective lifetime of the passivated $p$-type wafers in Fig. 7 is dominated by Auger recombination in the bulk of the $c$-Si wafer for injection levels $>5$ $\times 10^{15} \mathrm{~cm}^{-3}{ }^{49}$ For lower injection levels the effective lifetime is roughly flat for the $p$-type $c$-Si wafers passivated by 10 and $30 \mathrm{~nm}$ thick $\mathrm{Al}_{2} \mathrm{O}_{3}$ deposited on the FlexAL reactor and a $10 \mathrm{~nm}$ thick $\mathrm{Al}_{2} \mathrm{O}_{3}$ deposited on the ALD-I reactor. The $p$-type $c$-Si wafer passivated by the $30 \mathrm{~nm}$ thick film deposited on the ALD-I reactor, however, shows a decrease of the effective lifetime for lower injection levels. A similar injection level dependence of the effective lifetime (i.e., a decrease at lower injection levels) was reported by Agostinelli et al. for $2 \Omega \mathrm{cm} p$-type $c$-Si passivated by $\mathrm{Al}_{2} \mathrm{O}_{3}$ synthesized by thermal ALD. ${ }^{20}$ As shown in Fig. 8(a), the uniformity of the effective lifetime of the $c$-Si wafer passivated by a $30 \mathrm{~nm}$ thick $\mathrm{Al}_{2} \mathrm{O}_{3}$ film deposited on the ALD-I reactor was rather poor. We argue therefore that this nonuniformity of the effective lifetime over the $c$-Si wafer likely results in an apparent injection level dependence of the effective lifetime as determined by the photoconductance technique due to its rather large detection area of $\sim 6 \mathrm{~cm}^{2}{ }^{33}$ It should be noted that all of the $p$-type $c$-Si wafers passivated by $\mathrm{Al}_{2} \mathrm{O}_{3}$ films synthesized by plasma-assisted ALD on the FlexAL reactor demonstrated a good uniformity for the level of sur- 
face passivation as well as a fairly constant effective lifetime at low injection levels.

The flat injection level dependence of the effective lifetime at low injection levels is consistent with the extended Shockley-Read-Hall model proposed by Girish et al., ${ }^{51}$ because for $p$-type silicon the bulk minority charge carriers, the electrons, are effectively shielded from the $c$-Si surface by the negative fixed charge density present in the $\mathrm{Al}_{2} \mathrm{O}_{3}$ film. For dielectrics containing a positive fixed charge density (e.g., thermal $\mathrm{SiO}_{2}$ and $a-\mathrm{SiN}_{x}: \mathrm{H}$ ), the injection level dependence of the effective lifetime is flat for low injection levels on $n$-type $c$-Si when the bulk minority charge carrier, the holes, are shielded from the $c$-Si surface. ${ }^{1,6}$ On the other hand, $p$-type $c$-Si wafers passivated by dielectrics with a positive fixed charge density demonstrate a strong reduction of the effective lifetime for decreasing injection levels. ${ }^{1,6}$ This pronounced injection level dependence can primarily be attributed to the fact that in this case the bulk majority charge carriers, the holes, are shielded from the $c$-Si surface which results in an inversion layer at the $c$-Si surface. Consequently, from the results presented in the previous section and in this section, it can be concluded that the injection level dependence of the effective lifetime of $c$-Si passivated by the negative-charge dielectric of $\mathrm{Al}_{2} \mathrm{O}_{3}$ basically "mirrors" the injection level dependence for $c$-Si wafers passivated by the positive-charge dielectrics of thermal $\mathrm{SiO}_{2}$ and $a-\mathrm{SiN}_{x}: \mathrm{H}^{1,6}$ The effective lifetime can thus be made fairly constant at low injection levels for both $n$-type and $p$-type $c$-Si wafers by choosing a surface passivation dielectric with fixed charges whose polarity lead to shielding of bulk minority carriers from the $c$-Si surface. It should be realized that the injection level dependence of the effective lifetime is not only of academic interest. A low level of surface passivation at low injection levels is detrimental for low-light performance of $c$-Si solar cells and will therefore have a negative effect on their yearly $\mathrm{kW} \mathrm{h}$ output per watt peak, as shown by Aberle $e t$ al. ${ }^{3}$

Another aspect of high relevance is that when the positive-charge dielectric $a-\mathrm{SiN}_{x}: \mathrm{H}$ is applied at the rear of $p$-type $c$-Si solar cells, the positive fixed charge density causes a parasitic shunting effect which significantly lowers the $c$-Si solar cell efficiency. ${ }^{10}$ This parasitic shunting effect is not observed when the negative-charge dielectric $\mathrm{Al}_{2} \mathrm{O}_{3}$ is applied at the rear of $p$-type $c$-Si solar cells. ${ }^{52}$ The excellent level of surface passivation of lightly doped $p$-type $c$-Si by $\mathrm{Al}_{2} \mathrm{O}_{3}$ was recently confirmed by passivated emitter and rear cell solar cells in which $\mathrm{Al}_{2} \mathrm{O}_{3}$ yielded an equal performance as annealed thermal $\mathrm{SiO}_{2}$. An independently confirmed solar cell efficiency of $20.6 \%$ was obtained for these solar cells. ${ }^{52}$

In Fig. 9, the level of surface passivation obtained by $\mathrm{Al}_{2} \mathrm{O}_{3}$ films synthesized by plasma-assisted ALD on $p$-type $c$-Si is compared with the best results published to date for thermally grown $\mathrm{SiO}_{2}$, as-deposited $a-\mathrm{SiN}_{x}: \mathrm{H}$, and $a-\mathrm{Si}: \mathrm{H}$ [the latter two films were synthesized by plasma-enhanced chemical vapor deposition (PECVD)]. The surface recombination velocity for lightly $\mathrm{B}$-doped $c$-Si surfaces was calculated using the highest effective lifetimes reported in the literature assuming an infinite bulk lifetime (see Sec. III A). ${ }^{1,6,53}$ The surface recombination velocities at the

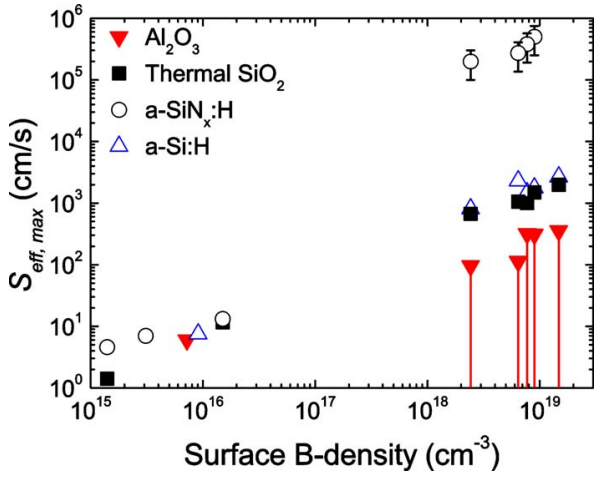

FIG. 9. (Color online) Upper level of the effective surface recombination velocity as a function of the B-density at the surface of $c$-Si wafers passivated by thermal $\mathrm{SiO}_{2}, a-\mathrm{SiN}_{x}: \mathrm{H}, a-\mathrm{Si}: \mathrm{H}$, and $\mathrm{Al}_{2} \mathrm{O}_{3}$. The values for highly B-doped surfaces for thermal $\mathrm{SiO}_{2}, a-\mathrm{Si}: \mathrm{H}$, and $\mathrm{Al}_{2} \mathrm{O}_{3}$ were taken from a previously published study (Ref. 32). The effective surface recombination values for low B-densities were calculated from the lifetime values reported by Kerr et al. and Dauwe et al. assuming an infinite bulk lifetime (Refs. 1, 6 , and 53). The $a-\mathrm{Si}: \mathrm{H}$ and $a-\mathrm{SiN}_{x}: \mathrm{H}$ films were grown by PECVD and the $\mathrm{Al}_{2} \mathrm{O}_{3}$ films were synthesized by plasma-assisted ALD. The $\mathrm{SiO}_{2}$ films were grown by thermal oxidation. The error bars are smaller than the symbol size unless indicated otherwise.

heavily B-doped $c$-Si surfaces were extracted from simulations by the device simulation package SENTUAURUS, as described by Altermatt et al. and Hoex et al. ${ }^{9,32}$ From Fig. 9, it is clear that $\mathrm{Al}_{2} \mathrm{O}_{3}$ provides a state-of-the-art level of surface passivation on $p$-type $c$-Si with an arbitrary doping level. The high negative fixed charge density effectively shields the bulk minority carriers (i.e., the electrons) from the $p$-type $c$-Si surfaces. Evidently, the level of surface passivation obtained by $\mathrm{Al}_{2} \mathrm{O}_{3}$ on low resistivity $p$-type $c$-Si is comparable to the best results reported for thermal $\mathrm{SiO}_{2}, a-\mathrm{SiN}_{x}: \mathrm{H}$, and $a-\mathrm{Si}: \mathrm{H}$ whereas heavily $\mathrm{B}$-doped $c$-Si surfaces are even more effectively passivated by $\mathrm{Al}_{2} \mathrm{O}_{3} \cdot{ }^{32}$ The excellent level of surface passivation of highly doped $p$-type $c$-Si by $\mathrm{Al}_{2} \mathrm{O}_{3}$ was recently confirmed by passivated emitter with rear locally diffused (PERL) solar cells in collaboration with the Fraunhofer ISE Institute. These $n$-type PERL solar cells in which $\mathrm{Al}_{2} \mathrm{O}_{3}$ was applied to passivate the $p$-type emitter yielded an independently confirmed solar cell efficiency of $23.2 \% .^{54}$

\section{Lightly-doped $p$-type $c$-Si passivated by thermal ALD $\mathrm{Al}_{2} \mathrm{O}_{3}$}

The results presented in this work so far were obtained for $\mathrm{Al}_{2} \mathrm{O}_{3}$ synthesized by plasma-assisted ALD. The study of Agostinelli et al. demonstrated that also $\mathrm{Al}_{2} \mathrm{O}_{3}$ films synthesized by thermal ALD with $\mathrm{H}_{2} \mathrm{O}$ as oxidizing agent can provide a very high level of surface passivation on $p$-type $c$-Si. ${ }^{20}$ Therefore, a brief experiment was carried out to directly investigate a possible influence of the oxidizing agent selected, i.e., the level of surface passivation obtained by thermal and plasma-assisted ALDs was compared by synthesizing the $\mathrm{Al}_{2} \mathrm{O}_{3}$ films by both processes in the same reactor.

The injection level dependent effective lifetime was determined for a $p$-type $c$-Si wafer $(2 \Omega \mathrm{cm},\langle 111\rangle)$ passivated by a $30 \mathrm{~nm} \mathrm{Al}_{2} \mathrm{O}_{3}$ synthesized by thermal and plasmaassisted ALD in the FlexAL reactor. As can be observed in 


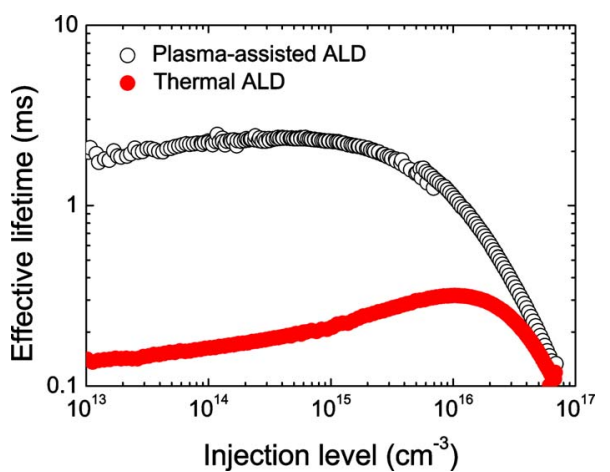

FIG. 10. (Color online) Injection level dependent effective lifetime of a $p$-type $c$-Si $(\mathrm{FZ}, 2 \Omega \mathrm{cm},\langle 111\rangle, 300 \mu \mathrm{m})$ wafer symmetrically passivated by a $30 \mathrm{~nm}$ thick $\mathrm{Al}_{2} \mathrm{O}_{3}$ film synthesized by plasma-assisted ALD and thermal ALD on the FlexAL reactor.

Fig. 10, the effective lifetime obtained with thermal ALD is significantly lower than the effective lifetime obtained with plasma-assisted $\mathrm{ALD} \mathrm{Al}_{2} \mathrm{O}_{3}$. For the thermal ALD process, the effective lifetime is $\sim 400 \mu$ s for an injection level of $1 \times 10^{16} \mathrm{~cm}^{-3}$ and shows the expected decrease due to the Auger recombination at higher injection levels. The effective lifetime for this sample is also significantly lower than the maximum effective lifetime of $950 \mu$ s (at an injection level of $1 \times 10^{15} \mathrm{~cm}^{-3}$ ), as reported by Agostinelli et al., despite the fact that they used a Czochralski grown $c$-Si wafer, which generally have a lower bulk lifetime. ${ }^{20}$ Remarkably, the effective lifetime for the thermal ALD $\mathrm{Al}_{2} \mathrm{O}_{3}$ film decreases at low injection levels for the $p$-type $c$-Si wafer which is in contrast to the constant effective lifetime observed at low injection levels when employing by plasmaassisted $\mathrm{ALD} \mathrm{Al}_{2} \mathrm{O}_{3}$ (see Sec. IV B).

As mentioned in Sec. II, the structural film properties of the $\mathrm{Al}_{2} \mathrm{O}_{3}$ films synthesized by thermal and plasma-assisted ALD on the FlexAL reactor were basically indistinguishable. $^{24}$ However, electrical measurements on both types of $\mathrm{Al}_{2} \mathrm{O}_{3}$ films revealed significant differences in the fixed charge density in the films. In Fig. 11, two $C-V$ curves are shown as typically obtained for MOS structures with an $\sim 20 \mathrm{~nm} \mathrm{Al}_{2} \mathrm{O}_{3}$ film synthesized by thermal and plasma-assisted ALDs in the FlexAL reactor. Similar to the lifetime samples, these MOS structures were annealed for 30

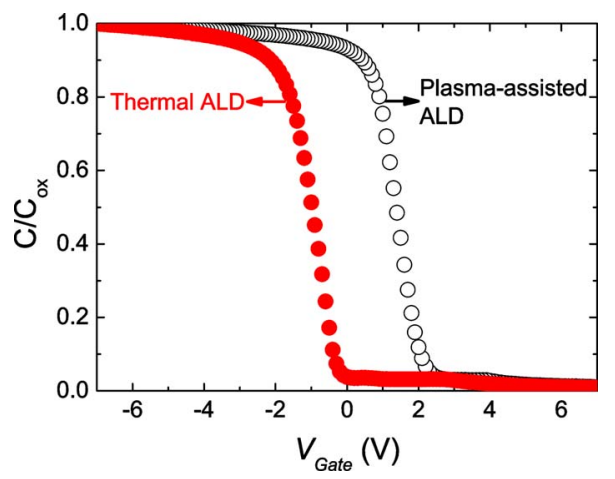

FIG. 11. (Color online) $C-V$ measurements of a MOS structure containing $20 \mathrm{~nm}$ thick $\mathrm{Al}_{2} \mathrm{O}_{3}$ films. The $\mathrm{Al}_{2} \mathrm{O}_{3}$ films were synthesized by thermal and plasma-assisted ALDs on a H-terminated 20-30 $\Omega \mathrm{cm} p$-type $c$-Si wafer and subsequently annealed for $30 \mathrm{~min}$ at $425^{\circ} \mathrm{C}$ in $\mathrm{N}_{2}$. min at $425{ }^{\circ} \mathrm{C}$ in $\mathrm{N}_{2}$. It can clearly be seen that the flatband voltage, which is related to the fixed charge density in the $\mathrm{Al}_{2} \mathrm{O}_{3},{ }^{55}$ is significantly different for the two films. The flatband voltage shift of the MOS structures corresponds to a negative fixed charge density of $1 \times 10^{12}$ and $7 \times 10^{12} \mathrm{~cm}^{-2}$ for the thermal and plasma-assisted $\mathrm{ALD} \mathrm{Al}_{2} \mathrm{O}_{3}$ films, respectively. From Fig. 5(b), it can be deduced that this difference in negative fixed charge density between the thermal and plasma-assisted $\mathrm{ALD} \mathrm{Al}_{2} \mathrm{O}_{3}$ films results in a $>50$ times higher surface recombination rate for the thermal ALD $\mathrm{Al}_{2} \mathrm{O}_{3}$ film. Consequently, the difference between the level of surface passivation of the thermal and plasma-assisted ALD $\mathrm{Al}_{2} \mathrm{O}_{3}$ films can be attributed mainly to a difference in level of field-effect passivation. Cho et al. and Kim et al. also reported significant differences in the electrical properties of thermal and plasma-assisted $\mathrm{ALD} \mathrm{Al}_{2} \mathrm{O}_{3} \cdot{ }^{56,57}$ The fact that the negative fixed charge density in the $\mathrm{Al}_{2} \mathrm{O}_{3}$ film synthesized by plasma-assisted ALD on the FlexAL reactor is lower than for the $26 \mathrm{~nm}$ thick film grown on the ALD-I reactor also explains the difference in the level of surface passivation obtained for the two reactors for films $<30 \mathrm{~nm}$ thick, as shown in Fig. 4.

From the electrical characterization it was found that the negative fixed charge density in plasma-assisted ALD $\mathrm{Al}_{2} \mathrm{O}_{3}$ films in the as-deposited state is significantly lower (up to one order of magnitude) than after the postdeposition annealing. It is therefore not expected that the $\mathrm{O}_{2}$ plasma itself results in this high fixed charge density. Moreover, Agostinelli et al. reported negative fixed charge densities up to 1 $\times 10^{13} \mathrm{~cm}^{-2}$ in their $\mathrm{Al}_{2} \mathrm{O}_{3}$ films synthesized by thermal ALD, but without specifying the post-thermal treatment applied. $^{20}$ It is therefore plausible that the optimal postdeposition annealing required to obtain the highest level of surface passivation is different for the thermal and plasmaassisted ALD synthesized $\mathrm{Al}_{2} \mathrm{O}_{3}$.

\section{CONCLUSIONS}

From the results reported in this paper, it is evident that $\mathrm{Al}_{2} \mathrm{O}_{3}$ films synthesized by plasma-assisted ALD are an interesting candidate for passivation of $c$-Si surfaces as required for the next-generation (high-efficiency) $c$-Si solar cells. The self-limiting nature of the ALD process results intrinsically in the precise thickness control and good thickness uniformity of the thin films. Moreover, the level of surface passivation provided by the low-temperature deposited $\mathrm{Al}_{2} \mathrm{O}_{3}$ films is at least equal to the state-of-the-art level of surface passivation obtained by high-temperature thermal $\mathrm{SiO}_{2}$ films on lightly doped $n$-type $c$-Si wafers and $p$-type $c$-Si wafers with an arbitrary doping level. The level of surface passivation by $\mathrm{Al}_{2} \mathrm{O}_{3}$ was determined by the techniques based on photoconductance, infrared emission, and photoluminescence showing an excellent agreement for $p$-type $c$-Si unless the $c$-Si wafer was nearly intrinsic. The excellent surface passivation by $\mathrm{Al}_{2} \mathrm{O}_{3}$ films can mainly be attributed to a high negative fixed charge density in the $\mathrm{Al}_{2} \mathrm{O}_{3}$, as directly demonstrated in this work. A negative fixed charge density is shown to be especially beneficial for the passivation of (highly doped) $p$-type $c$-Si as the bulk minority charge car- 


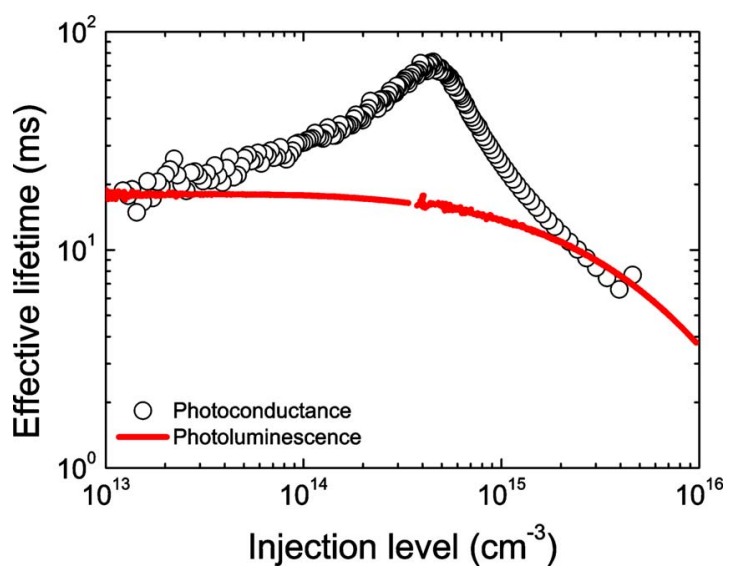

FIG. 12. (Color online) Injection level dependent effective lifetime of a nearly intrinsic $n$-type $c$-Si wafer $(2 \mathrm{k} \Omega \mathrm{cm},\langle 111\rangle, 300 \mu \mathrm{m})$ symmetrically passivated by a $30 \mathrm{~nm} \mathrm{Al}_{2} \mathrm{O}_{3}$ film. The effective lifetime was measured by photoconductance (both in PCD and QSSPC modes) and quasi-steady-state photoluminescence.

riers, the electrons, are effectively shielded from the $c$-Si surface. Thermal ALD $\mathrm{Al}_{2} \mathrm{O}_{3}$ demonstrated a significantly lower level of surface passivation compared to plasmaassisted ALD $\mathrm{Al}_{2} \mathrm{O}_{3}$ when using the same ALD reactor and identical pre- and postdeposition processing. It was discussed that this discrepancy can be attributed to a significantly higher negative fixed charge density in the plasmaassisted $\mathrm{ALD} \mathrm{Al}_{2} \mathrm{O}_{3}$ films compared to the thermal ALD $\mathrm{Al}_{2} \mathrm{O}_{3}$ films.

\section{ACKNOWLEDGMENTS}

The authors thank W. Keuning, J. L. van Hemmen, M. J. F. van de Sande, J. F. C. Jansen, and J. J. A. Zeebregts for their technical assistance and help during the experiments. E. J. Geluk, E. Smalbrugge, and T. de Vries are thanked for their assistance in the clean room operation. Dr. T. Trupke (University of New South Wales) and Dr. K. R. McIntosh (Australian National University) are acknowledged for the quasi-steady-state photoluminescence measurements and the fruitful discussions on the photoconductance data for highresistivity $c$-Si wafers, respectively. This work is supported by the Netherlands Technology Foundation STW and the German State of Lower Saxony. The work of B. H. is financially supported by OTB Solar.

\section{APPENDIX: EFFECTIVE LIFETIME FOR NEARLY INTRINSIC $\boldsymbol{C}$-SI AS DETERMINED BY THE PHOTOCONDUCTANCE AND PHOTOLUMINESCENCE TECHNIQUES}

Figure 12 shows the injection level dependence of the effective lifetime as determined from the photoconductance and photoluminescence techniques for nearly intrinsic $n$-type $c$-Si $(2 \mathrm{k} \Omega \mathrm{cm},\langle 111\rangle)$ wafer symmetrically passivated by a $30 \mathrm{~nm} \mathrm{Al}_{2} \mathrm{O}_{3}$ film synthesized by plasma-assisted ALD. It can be seen that a strong discrepancy exists between the two results. The photoluminescence measurement shows a constant effective lifetime of $18 \mathrm{~ms}$ at low injection levels and a decrease at higher injection levels due to the Auger recombination. The photoconductance data show a pronounced be- havior with an extremely high effective lifetime of $72 \mathrm{~ms}$ at an injection level of $(2-4) \times 10^{14} \mathrm{~cm}^{-3}$. A similar, but less pronounced, anomalous behavior of the effective lifetime was deduced from photoconductance measurements for the $90 \Omega \mathrm{cm} n$-type $c$-Si passivated with forming gas annealed thermal $\mathrm{SiO}_{2}$ by Kerr et al. ${ }^{1}$ If the photoconductance measurement in Fig. 12 would be affected by depletion region modulation or carrier trapping, the effective lifetime would demonstrate an increase for a decreasing injection level, ${ }^{34,35}$ which implies that this kind of artifacts cannot explain the anomalous behavior observed. To date no physical mechanism has been reported that can explain the subsequent decrease in the effective lifetime for injection levels lower than $2 \times 10^{14} \mathrm{~cm}^{-3}$. However, by McIntosh et al. it was shown that the photoconductance voltage inductively measured by the Sinton WCT-100 (Ref. 33) lifetimetester, which is routinely used within the photovoltaics community, shows a strong nonlinearity for a conductance lower than $1 \mathrm{mS}$ (i.e., corresponding to a $300 \mu \mathrm{m} c$-Si wafer with a resistivity of $>30 \Omega \mathrm{cm}) .{ }^{40}$ Although the physical origin of this nonlinearity is still under investigation, this nonlinear response can likely explain the particular values of the effective lifetime deduced from the photoconductance measurements for these high-resistivity $n$-type $c$-Si wafers. Accordingly, for the highresistivity $c$-Si wafers employed in this work, it was decided to use the effective lifetimes extracted from the photoluminescence measurements with the self-consistent calibration proposed by Trupke et al. ${ }^{37}$

${ }^{1}$ M. J. Kerr and A. Cuevas, Semicond. Sci. Technol. 17, 35 (2002).

${ }^{2}$ W. Fussel, M. Schmidt, H. Angermann, G. Mende, and H. Flietner, Nucl. Instrum. Methods Phys. Res. A 377, 177 (1996).

${ }^{3}$ A. G. Aberle, S. Glunz, and W. Warta, J. Appl. Phys. 71, 4422 (1992).

${ }^{4}$ J. Zhao, A. H. Wang, and M. A. Green, Sol. Energy Mater. Sol. Cells 66, 27 (2001).

${ }^{5}$ P. M. Mulligan, D. H. Rose, M. J. Cudzinovic, and D. M. de Ceuster, Proceedings of the 19th EU-PVSEC, Paris (WIP Renewable Energies, Munich, 2004), p. 387.

${ }^{6}$ M. J. Kerr and A. Cuevas, Semicond. Sci. Technol. 17, 166 (2002).

${ }^{7}$ T. Lauinger, J. Schmidt, A. G. Aberle, and R. Hezel, Appl. Phys. Lett. 68, 1232 (1996).

${ }^{8}$ R. Hezel and K. Jaeger, J. Electrochem. Soc. 136, 518 (1989).

${ }^{9}$ P. P. Altermatt, H. Plagwitz, R. Bock, J. Schmidt, R. Brendel, M. J. Kerr, and A. Cuevas, Proceedings of the 21st EU-PVSEC, Dresden (WIP Renewable Energies, Munich, 2006), p. 647.

${ }^{10}$ S. Dauwe, L. Mittelstadt, A. Metz, and R. Hezel, Prog. Photovoltaics 10, 271 (2002).

${ }^{11}$ F. W. Chen, T. T. A. Li, and J. E. Cotter, Appl. Phys. Lett. 88, 263514 (2006).

${ }^{12}$ V. D. Mihailetchi, Y. Komatsu, and L. J. Geerligs, Appl. Phys. Lett. 92, 063510 (2008).

${ }^{13}$ M. Taguchi, K. Kawamoto, S. Tsuge, T. Baba, H. Sakata, M. Morizane, K. Uchihashi, N. Nakamura, S. Kiyama, and O. Oota, Prog. Photovoltaics 8, $503(2000)$

${ }^{14}$ M. Garin, U. Rau, W. Brendle, I. Martin, and R. Alcubilla, J. Appl. Phys. 98, 093711 (2005).

${ }^{15}$ S. Olibet, E. Vallat-Sauvain, and C. Ballif, Phys. Rev. B 76, 035326 (2007).

${ }^{16}$ M. Schaper, J. Schmidt, H. Plagwitz, and R. Brendel, Prog. Photovoltaics 13, 381 (2005).

${ }^{17}$ T. Lauinger, J. Moschner, A. G. Aberle, and R. Hezel, J. Vac. Sci. Technol. A 16, 530 (1998).

${ }^{18}$ P. E. Gruenbaum, R. A. Sinton, and R. M. Swanson, Appl. Phys. Lett. 52, 1407 (1988).

${ }^{19}$ A. G. Aberle and R. Hezel, Prog. Photovoltaics 5, 29 (1997).

${ }^{20}$ G. Agostinelli, A. Delabie, P. Vitanov, Z. Alexieva, H. F. W. Dekkers, S. De Wolf, and G. Beaucarne, Sol. Energy Mater. Sol. Cells 90, 3438 
(2006).

${ }^{21}$ B. Hoex, S. B. S. Heil, E. Langereis, M. C. M. van de Sanden, and W. M. M. Kessels, Appl. Phys. Lett. 89, 042112 (2006).

${ }^{22}$ R. L. Puurunen, J. Appl. Phys. 97, 121301 (2005).

${ }^{23}$ S. D. Elliott, G. Scarel, C. Wiemer, M. Fanciulli, and G. Pavia, Chem. Mater. 18, 3764 (2006).

${ }^{24}$ J. L. van Hemmen, S. B. S. Heil, J. Klootwijk, F. Roozeboom, C. J. Hodson, M. C. M. van de Sanden, and W. M. M. Kessels, J. Electrochem. Soc. 154, G165 (2007).

${ }^{25}$ S. B. S. Heil, E. Langereis, F. Roozeboom, M. C. M. van de Sanden, and W. M. M. Kessels, J. Electrochem. Soc. 153, G956 (2006).

${ }^{26}$ S. B. S. Heil, J. L. Hemmen, C. J. Hodson, N. Singh, J. H. Klootwijk, F. Roozeboom, M. C. M. van de Sanden, and W. M. M. Kessels, J. Vac. Sci. Technol. A 25, 1357 (2007).

${ }^{27}$ S. B. S. Heil, P. Kudlacek, E. Langereis, R. Engeln, M. C. M. van de Sanden, and W. M. M. Kessels, Appl. Phys. Lett. 89, 131505 (2006).

${ }^{28} \mathrm{~J}$. Humlicek, Handbook of Ellipsometry (William Andrew, New York, 2005).

${ }^{29}$ T. Yasuda and D. E. Aspnes, Appl. Opt. 33, 7435 (1994).

${ }^{30}$ W. Kern, J. Electrochem. Soc. 137, 1887 (1990).

${ }^{31}$ E. Yablonovitch, D. L. Allara, C. C. Chang, T. Gmitter, and T. B. Bright, Phys. Rev. Lett. 57, 249 (1986).

${ }^{32}$ B. Hoex, J. Schmidt, R. Bock, P. P. Altermatt, M. C. M. van de Sanden, and W. M. M. Kessels, Appl. Phys. Lett. 91, 112107 (2007).

${ }^{33}$ R. A. Sinton and A. Cuevas, Appl. Phys. Lett. 69, 2510 (1996).

${ }^{34}$ P. J. Cousins, D. H. Neuhaus, and J. E. Cotter, J. Appl. Phys. 95, 1854 (2004).

${ }^{35}$ D. Macdonald and A. Cuevas, Appl. Phys. Lett. 74, 1710 (1999).

${ }^{36}$ T. Trupke and R. A. Bardos, Proceedings of the IEEE PVSEC, Lake Buena Vista, FL (IEEE, Piscataway, NJ, 2005), p. 903.

${ }^{37}$ T. Trupke, R. A. Bardos, and M. D. Abbott, Appl. Phys. Lett. 87, 184102 (2005).

${ }^{38} \mathrm{P}$. Pohl and R. Brendel, Proceedings of the 19th European PVSEC, Paris (WIP Renewable Energies, Munich, 2004), p. 46.
${ }^{39}$ P. Pohl, J. Schmidt, K. Bothe, and R. Brendel, Appl. Phys. Lett. 87, 142104 (2005)

${ }^{40}$ K. R. McIntosh, J. H. Guo, M. D. Abbott, and R. A. Bardos, Prog. Photovoltaics 16(4), 279 (2008).

${ }^{41}$ S. Dauwe, J. Schmidt, A. Metz, and R. Hezel, Proceedings of the 29th IEEE Photovoltaic Specialist Conference, New Orleans (IEEE, Piscataway, NJ, 2002), p. 162.

${ }^{42}$ S. W. Glunz, D. Biro, S. Rein, and W. Warta, J. Appl. Phys. 86, 683 (1999).

${ }^{43}$ M. M. Shahin, J. Chem. Phys. 45, 2600 (1966)

${ }^{44}$ R. Ferre, I. Martin, M. Vetter, M. Garin, and R. Alcubilla, Appl. Phys. Lett. 87, 202109 (2005).

${ }^{45}$ J. R. Elmiger, R. Schieck, and M. Kunst, J. Vac. Sci. Technol. A 15, 2418 (1997).

${ }^{46}$ S. De Wolf and G. Beaucarne, Appl. Phys. Lett. 88, 022104 (2006).

${ }^{47}$ P. A. Basore, IEEE Trans. Electron Devices 37, 337 (1990).

${ }^{48}$ A. G. Aberle, S. Glunz, and W. Warta, Sol. Energy Mater. Sol. Cells 29, 175 (1993).

${ }^{49}$ M. J. Kerr and A. Cuevas, J. Appl. Phys. 91, 2473 (2002).

${ }^{50}$ M. Bail, M. Schulz, and R. Brendel, Appl. Phys. Lett. 82, 757 (2003).

${ }^{51}$ R. B. M. Girisch, R. P. Mertens, and R. F. Dekeersmaecker, IEEE Trans. Electron Devices 35, 203 (1988).

${ }^{52}$ J. Schmidt, A. Merkle, R. Brendel, B. Hoex, M. C. M. van de Sanden, and W. M. M. Kessels, Prog. Photovoltaics 16(6), 461 (2008).

${ }^{53}$ S. Dauwe, J. Schmidt, and R. Hezel, Proceedings of the 29th IEEE Photovoltaic Specialist Conference, New Orleans (IEEE, Piscataway, NJ, 2002), p. 1246.

${ }^{54}$ J. Benick, B. Hoex, M. C. M. van de Sanden, W. M. M. Kessels, O. Schultz, and S. Glunz, Appl. Phys. Lett. 92, 253504 (2008)

${ }^{55}$ D. K. Schroder, Semiconductor Material and Device Characterization, 3rd ed. (Wiley-Interscience, Hoboken, NJ, 2006).

${ }^{56}$ M. Cho, H. B. Park, J. Park, S. W. Lee, C. S. Hwang, J. Jeong, H. S. Kang, and Y. W. Kim, J. Electrochem. Soc. 152, F49 (2005).

${ }^{57}$ J. W. Lim and S. J. Yun, Electrochem. Solid-State Lett. 7, F45 (2004). 